\title{
Greenhouse Screening of Corn Gluten Meal as a Natural Control Product for Broadleaf and Grass Weeds
}

\author{
Barbara R. Bingaman ${ }^{1}$ and Nick E. Christians ${ }^{2}$ \\ Department of Horticulture, Iowa State University, Ames, IA 50011
}

Additional index words. corn by-product, weed management, natural herbicide, pest management

\begin{abstract}
Corn (Zea mays L.) gluten meal (CGM) was evaluated under greenhouse conditions for efficacy on 22 selected monocotyledonous and dicotyledonous weed species. Corn gluten meal was applied at $0,324,649$, and $973 \mathrm{~g} \cdot \mathrm{m}^{-2}$ and as a soil-surface preemergence (PRE) and preplant-incorporated (PPI) weed control product. CGM reduced plant survival, shoot length, and root development of all tested species. Black nightshade (Solanum nigrum L.), common lambsquarters (Chenopodium album L.), creeping bentgrass (Agrostis palustris Huds.), curly dock (Rumex crispus L.), purslane (Portulaca oleracea L.), and redroot pigweed (Amaranthus retroflexus L.) were the most susceptible species. Plant survival and root development for these species were reduced by $\geq 75 \%$, and shoot length was decreased by $>50 \%$ when treated PRE and PPI with $324 \mathrm{~g}$ $\mathrm{CGM} / \mathrm{m}^{2}$. Catchweed bedstraw (Galium aparine L.), dandelion (Taraxacum officinale Weber), giant foxtail (Setaria faberi Herrm.), and smooth crabgrass [Digitaria ischaemum (Schreb.) Schreb. ex Muhl] exhibited survival and shoot length reductions $>50 \%$ and an $80 \%$ reduction in root development when treated with PPI CGM at $324 \mathrm{~g} \cdot \mathrm{m}^{-2}$. Barnyardgrass [Echinochloa crus-galli (L.) Beauv.] and velvetleaf (Abutilon theophrasti Medic.) were the least susceptible species showing survival reductions $\leq 31 \%$ when treated with 324 g CGM $/ \mathrm{m}^{2}$.
\end{abstract}

Synthetic herbicides often are used for weed control in vegetable crop and turfgrass management systems. Public awareness of the widespread use of herbicides and the possible negative effects of their residues on the environment are incentives for researchers to identify natural plant substances with herbicidal properties.

Several researchers have reported inhibition of shoot and root elongation of selected plant species by corn stalks and residue (Bonner, 1950; Nielsen et al., 1960). Watersoluble extracts from cornstalks significantly inhibited the root and shoot growth of wheat (Triticum aestivum L.) and sorghum [Sorghumbicolor (L.) Moench.] seedlings (Guenzi and McCalla, 1962). In addition, aqueous extracts from decomposing corn residues suppressed root elongation in lettuce (Lactuca sativa L. 'Great Lakes'), suggesting that inhibition resulted from damage to the meristematic tissue of the emerging radicles (Chou and Patrick, 1976). Recent research has shown that corn gluten meal (CGM), the protein fraction of corn grain extracted in the wetmilling process, effectively controlled several weed species and has potential for use as a

Received for publication 3 Jan. 1995. Accepted for publication 1 May 1995. This is Journal Paper no. J15830 of the Iowa Agriculture and Home Economics Expt. Station, Ames. Project no. 3149. The cost of publishing this paper was defrayed in part by the payment of page charges. Under postal regulations, this paper therefore must be hereby marked advertisement solely to indicate this fact.

${ }^{1}$ Postdoctoral Research Associate.

${ }^{2}$ Professor. natural herbicide in turfgrass (Christians, 1993) and strawberry (Fragaria $\times$ ananassa Duch.) weed management programs (Nonnecke and Christians, 1993).

Root formation during germination is inhibited by CGM in susceptible species. When CGM-treated plants were subjected to moisture stress, they died (Christians, 1993). In addition, CGM contains $\approx 10 \% \mathrm{~N}$ by weight and provides an additional $\mathrm{N}$ source to plant species with well-developed root systems. United States patent 5,030,268 has been granted for using CGM as a surface-applied preemergence herbicide (Christians, 1991).

Our objective was to evaluate the effects of CGM on plant survival and shoot and root growth of selected monocotyledonous and dicotyledonous weeds.

\section{Materials and Methods}

Twenty-two plant species were screened for susceptibility to CGM. The 10 dicotyledonous species used were black medic (Medicago lupulina L.), black nightshade, buckhorn plantain (Plantago lanceolata L.), catchweed bedstraw, common lambsquarters, curly dock, dandelion, purslane, redroot pigweed, and velvetleaf. Twelve monocotyledonous species were screened: annual bluegrass (Poa annua L.), barnyardgrass, creeping bentgrass, giant foxtail, green foxtail [Setaria viridis (L.) Beauv.], large crabgrass [Digitaria sanguinalis (L.) Scop.], orchardgrass (Dactylis glomerta L.), quackgrass [Agropyron repens (L.) Beauv.], shattercane (Sorghum bicolor L.), smooth crabgrass, woolly cupgrass [Eriochloa villosa (Thunb.) Kunth], and yel- low foxtail [Setaria lutescens (Weigel) Hubb.].

All plants were grown under greenhouse conditions in square plastic pots with a surface area of $46.2 \mathrm{~cm}^{2}$ and a depth of $5.7 \mathrm{~cm}$. The planting medium was a Nicollet (fine-loamy mixed mesic Aquic Hapludolls) soil with a pH of 7.6 and $32 \mathrm{~g}$ organic matter $/ \mathrm{kg}, 22 \mathrm{ppm}$ extractable $\mathrm{P}$, and $160 \mathrm{ppm}$ exchangeable $\mathrm{K}$. All seeds were planted to a depth of $0.6 \mathrm{~cm}$. The number of seeds planted in each pot was species specific and was determined from previously obtained germination data (Table 1). Species with very small seeds were planted on a weight basis. Plants were watered to keep the soil uniformly moist, and no pesticides were applied. Because of the short duration of each test, no additional fertilizer was added.

CGM was applied at $0,324,649$, and 973 $\mathrm{g} \cdot \mathrm{m}^{-2}$. These treatment levels were selected based on previous greenhouse research (Christians, 1993). CGM was applied to the soil surface for the preemergence (PRE) treatments. For the preplant-incorporated (PPI) treatments, CGM was uniformly mixed in the upper $2.5 \mathrm{~cm}$ of soil in the pots.

Two studies were conducted in 1992, each with three replications: the first in late summer with natural lighting and the second in the fall using supplemental lighting from highpressure sodium lamps to enhance the natural irradiance and to extend the daylength to $16 \mathrm{~h}$. These lights delivered $\approx 70 \mu \mathrm{mol} \cdot \mathrm{m}^{-2} \cdot \mathrm{s}^{-1}$ of irradiance.

The duration of each test was 16 days. On the last day, plant survival was assessed by counting the number of living plants in each pot, and shoot length was measured as the average length of the surviving plants. The soil residue was washed from the roots to examine the effects of CGM on rooting. The roots of CGM-treated plants were compared visually with the roots of nontreated plants. Differ-

Table 1. Number and weight of seeds planted in each pot for the 22 species of plants screened.

\begin{tabular}{lcc}
\hline Plant & $\begin{array}{c}\text { No. } \\
\text { species }\end{array}$ & $\begin{array}{c}\text { Wt } \\
\text { seeds/pot }\end{array}$ \\
\hline Annual bluegrass & 500 & $0.219^{\mathrm{z}}$ \\
Barnyardgrass & 25 & 0.101 \\
Black medic & 50 & $0.074^{\mathrm{z}}$ \\
Black nightshade & 15 & 0.020 \\
Buckhorn plantain & 200 & $0.500^{\mathrm{z}}$ \\
Catchweed bedstraw & 25 & 0.077 \\
Common lambsquarters & 150 & $0.120^{\mathrm{z}}$ \\
Creeping bentgrass & 1000 & $0.200^{\mathrm{z}}$ \\
Curly dock & 100 & $0.078^{\mathrm{z}}$ \\
Dandelion & 15 & 0.008 \\
Giant foxtail & 25 & 0.040 \\
Green foxtail & 50 & 0.055 \\
Large crabgrass & 500 & $0.200^{\mathrm{z}}$ \\
Orchardgrass & 50 & 0.060 \\
Purslane & 100 & $0.080^{\mathrm{z}}$ \\
Quackgrass & 30 & 0.097 \\
Redroot pigweed & 25 & 0.007 \\
Shattercane & 30 & 0.490 \\
Smooth crabgrass & 100 & $0.200^{\mathrm{z}}$ \\
Velvetleaf & 15 & 0.142 \\
Woolly cupgrass & 15 & 0.126 \\
Yellow foxtail & 15 & 0.046 \\
\hline Becauseofthesmall & &
\end{tabular}

${ }^{2}$ Because of the small seed size of these species, they were planted on the basis of weight per pot. The number of seeds per pot is a mean count. 
ences between the amount of rooting for CGMtreated plants and nontreated plants were estimated and recorded as percent reductions in root development. Reductions were estimated in $5 \%$ increments.

The statistical design was a split-split plot. The four CGM treatment levels were the wholeplot treatments; the two application methods, the subplot treatments, and the weed species the sub-subplots. The results were similar for the two studies; therefore, data from both were combined for analysis.

The three replications in the first study were run consecutively because of space limitations, and those for the second study were run concurrently. Data were analyzed with the SAS version 6.6 (SAS Institute, 1990) analysis of variance procedure to test the significance of CGM effects on plant survival, shoot length, and root development. Least significant difference tests were used to compare significantly different means (Cochran and Cox, 1957).

\section{Results}

Plant survival. CGM reduced the survival of all broadleaf and grass species (Tables 2 and $3)$. There were no differences in the survival of plants receiving PRE applications and PPI treatments (Table 2).

There was a wide degree of interspecific variation in plant survival of CGM-treated plants (Table 3). Survival of all species, except barnyardgrass, green foxtail, quackgrass, velvetleaf, and woolly cupgrass, was reduced $\geq 40 \%$ when treated with $324 \mathrm{~g} \mathrm{CGM} / \mathrm{m}^{2}$, and eight broadleaf species incurred $75 \%$ reductions at this CGM level. Reductions in survival were $\geq 75 \%$ for 11 of the species treated with $649 \mathrm{~g} \mathrm{CGM} / \mathrm{m}^{2}$, and the survival of six additional species was reduced $>40 \%$. At $973 \mathrm{~g}$ $\mathrm{CGM} / \mathrm{m}^{2}$, survival was reduced $\geq 63 \%$ for all species except barnyardgrass, shattercane, and velvetleaf (Table 3 ).

There also were differences among species in their response to CGM quantity (Table 2). Survival decreased for 15 broadleaf and grass species as the amount of applied CGM increased (Table 3 ). Survival reductions were $\geq 95 \%$ for purslane and $\geq 87 \%$ for redroot pigweed at all CGM quantities. The survival of 20 species was decreased $\geq 50 \%$ by $973 \mathrm{~g} \mathrm{CGM} / \mathrm{m}^{2}$, and eight broadleaf and four grass species experienced reductions $\geq 90 \%$. Survival was reduced $\leq 51 \%$ at all CGM levels for barnyardgrass, shattercane, and velvetleaf.

Seven broadleaf and one grass species had the fewest survivors. At $324 \mathrm{~g} \mathrm{CGM} / \mathrm{m}^{2}$, survival of black nightshade, buckhorn plantain, common lambsquarters, creeping bentgrass, curly dock, dandelion, purslane, and redroot pigweed was reduced $\geq 75 \%$. Annual bluegrass, catchweed bedstraw, giant foxtail, large crabgrass, orchardgrass, and smooth crabgrass showed survival reductions $\geq 51 \%$ at $324 \mathrm{~g}$ $\mathrm{CGM} / \mathrm{m}^{2}$. At this same CGM level, all quackgrass and velvetleaf plants survived, as did nearly all woolly cupgrass seedlings.

Shoot length. There was a wide range of interspecific variation in shoot length reduc- tion at the various CGM treatment levels (Table 2). Shoot lengths decreased for 13 broadleaf and grass species as the amount of applied CGM increased (Table 4). Black medic, black nightshade, common lambsquarters, curly dock, dandelion, purslane, and redroot pigweed had shoot lengths $>50 \%$ shorter than the control at all CGM levels. Green foxtail receiving PRE applications exhibited $0 \%$ reduction in shoot length at $324 \mathrm{~g} \mathrm{CGM} / \mathrm{m}^{2}, 10 \%$ at $649 \mathrm{~g} \mathrm{CGM} / \mathrm{m}^{2}$, and did not grow at $973 \mathrm{~g}$ $\mathrm{CGM} / \mathrm{m}^{2}$. At $649 \mathrm{~g} \mathrm{CGM} / \mathrm{m}^{2}$ black nightshade died, and buckhorn plantain, curly dock, dandelion, and redroot pigweed had $\geq 80 \%$ less shoot growth than the control for PRE and PPI CGM. Curly dock and redroot pigweed exhibited $>90 \%$ shoot reduction, and black nightshade, common lambsquarters, dandelion, and green foxtail died with PRE and PPI at $973 \mathrm{~g}$ $\mathrm{CGM} / \mathrm{m}^{2}$.

The species $\times$ application method interaction was significant for shoot length (Table 2).
Most species treated with PPICGM had shorter shoots than those treated with PRE applications (Table 4). Shoot lengths of buckhorn plantain, catchweed bedstraw, giant foxtail, green foxtail, and quackgrass were reduced $\leq 22 \%$ by $324 \mathrm{~g} \mathrm{PRE} \mathrm{CGM} / \mathrm{m}^{2}$ but were reduced $\geq 50 \%$ by PPI applications at this level. With PRE at $649 \mathrm{~g} \mathrm{CGM} / \mathrm{m}^{2}$, large crabgrass, and yellow foxtail exhibited shoot reductions of $6 \%$ and $0 \%$, respectively, but with PPI $\mathrm{CGM}$ at this level, they showed reductions of $49 \%$ and $87 \%$, respectively. Treatment with a PRE application at $973 \mathrm{~g} \mathrm{CGM} / \mathrm{m}^{2}$ reduced shoot length $\leq 32 \%$ for quackgrass, shattercane, woolly cupgrass, and yellow foxtail; shoot lengths of barnyardgrass and large crabgrass were not reduced. PPI applications of $973 \mathrm{~g}$ $\mathrm{CGM} / \mathrm{m}^{2}$, however, resulted in $\geq 51 \%$ shoot length reductions for all species, and shoot lengths were decreased $55 \%$ for barnyardgrass and $87 \%$ for large crabgrass.

Root development. Rooting of all broad-

Table 2. Analysis of variance for a split-split-plot design showing the significance of corn gluten meal effects on plant survival, shoot length, and root development. ${ }^{\mathrm{z}}$

\begin{tabular}{lrccc}
\hline & & & $P>\mathrm{F}$ & \\
\cline { 3 - 5 } Source & & Plant & Shoot \\
survival & 0.0008 & 0.0007 & $\begin{array}{c}\text { Root } \\
\text { length }\end{array}$ & 0.0001 \\
\hline Replication (Rep) & 5 & 0.0001 & 0.0001 & 0.0001 \\
Corn gluten meal (CGM) & 3 & 0.1463 & 0.3182 & 0.0018 \\
Rep $\times$ CGM & 15 & 0.4864 & 0.0001 & 0.0001 \\
Application method (AM) & 1 & 0.0001 & 0.0001 & 0.0001 \\
Species & 21 & 0.1188 & 0.0056 & 0.0001 \\
AM $\times$ species & 21 & 0.0001 & 0.0001 & 0.0001 \\
Rep $\times$ AM $\times$ species & 215 & 0.5160 & 0.0015 & 0.0001 \\
CGM $\times$ AM & 3 & 0.0054 & 0.0001 & 0.0001 \\
CGM $\times$ species & 63 & 0.2691 & 0.0532 & 0.0003 \\
CGM $\times$ AM $\times$ species & 63 & & & \\
Error $($ c) & 645 & & &
\end{tabular}

${ }^{\mathrm{z}}$ Data from both studies were combined.

y This source is error (a).

${ }^{x}$ This source is replication $\times$ application method $\times$ species and is error $(b)$.

Table 3. Reductions in survival, relative to the control, of weeds treated with three quantities of corn gluten meal (CGM). ${ }^{\mathrm{z}}$

\begin{tabular}{|c|c|c|c|}
\hline \multirow{3}{*}{$\begin{array}{l}\text { Weed } \\
\text { species }\end{array}$} & \multicolumn{3}{|c|}{$\%$ Reduction $^{y}$} \\
\hline & \multicolumn{3}{|c|}{ Quantity of CGM } \\
\hline & $324 \mathrm{~g} \cdot \mathrm{m}^{-2}$ & $649 \mathrm{~g} \cdot \mathrm{m}^{-2}$ & $973 \mathrm{~g} \cdot \mathrm{m}^{-2}$ \\
\hline Annual bluegrass & 60 & 81 & 72 \\
\hline Barnyardgrass & 31 & 35 & 41 \\
\hline Black medic & 49 & 63 & 63 \\
\hline Black nightshade & 78 & 99 & 100 \\
\hline Buckhorn plantain & 80 & 95 & 96 \\
\hline Catchweed bedstraw & 66 & 33 & 94 \\
\hline Common lambsquarters & 82 & 88 & 99 \\
\hline Creeping bentgrass & 85 & 85 & 96 \\
\hline Curly dock & 75 & 94 & 97 \\
\hline Dandelion & 75 & 90 & 100 \\
\hline Giant foxtail & 63 & 54 & 83 \\
\hline Green foxtail & 37 & 78 & 100 \\
\hline Large crabgrass & 51 & 70 & 82 \\
\hline Orchardgrass & 56 & 53 & 92 \\
\hline Purslane & 97 & 95 & 100 \\
\hline Quackgrass & 0 & 20 & 71 \\
\hline Redroot pigweed & 87 & 96 & 99 \\
\hline Shattercane & 42 & 43 & 51 \\
\hline Smooth crabgrass & 51 & 85 & 97 \\
\hline Velvetleaf & 0 & 18 & 35 \\
\hline Woolly cupgrass & 6 & 29 & 79 \\
\hline Yellow foxtail & 43 & 65 & 78 \\
\hline
\end{tabular}

${ }^{\mathrm{z}}$ Least significant difference $\left(\mathrm{LSD}_{0.05}=40\right)$ for mean comparisons among CGM quantities for each species. y These data include the results of two studies and are mean percentages of the surface-applied (PRE) and preplant-incorporated (PPI) survival reductions relative to the survival of the control plants $(n=12)$. 
leaf and grass species was reduced by CGM (Tables 2 and 5). Reduction in root development significantly differed among CGM levels and species (Table 2). Interspecific variation in rooting ranged widely at all CGM levels (Table 5). With increasing amounts of applied CGM, root development decreased for black nightshade, buckhorn plantain, common lambsquarters, dandelion, quackgrass, and smooth crabgrass. Rooting reductions were $\geq 80 \%$ at all PRE and PPI levels for black medic, black nightshade, curly dock, creeping bentgrass, and purslane. Buckhorn plantain, catchweed bedstraw, common lambsquarters, dandelion, giant foxtail, green foxtail, orchardgrass, smooth crabgrass, and yellow foxtail had root development reduced $>80 \%$ at all PPI levels. Rooting decreased $\leq 45 \%$ at all PRECGM levels for barnyardgrass, large crabgrass, shattercane, and woolly cupgrass.

The species $\times$ application method interaction was significant (Table 2). Dandelion, green foxtail, and yellow foxtail had $\leq 35 \%$ rooting reductions when treated with $324 \mathrm{~g}$ PRE $\mathrm{CGM} / \mathrm{m}^{2}$ but exhibited $\geq 90 \%$ reductions when subjected to PPI applications at the same level (Table 5). Large crabgrass root development was not decreased with $324 \mathrm{~g}$ PRE CGM $/ \mathrm{m}^{2}$ but was reduced $80 \%$ with $324 \mathrm{~g}$ PPICGM $/ \mathrm{m}^{2}$. Root development reductions were $\leq 55 \%$ for annual bluegrass, catchweed bedstraw, large crabgrass, woolly cupgrass, and yellow foxtail with $649 \mathrm{~g}$ PRE CGM $/ \mathrm{m}^{2}$ but were $\geq 90 \%$ with $649 \mathrm{~g}$ PPI CGM $/ \mathrm{m}^{2}$. PPI applications at $973 \mathrm{~g}$ $\mathrm{CGM} / \mathrm{m}^{2}$ resulted in $\geq 75 \%$ root development reductions for all species. PRE applications at this CGM level, however, reduced rooting $\leq 45 \%$ for barnyardgrass, large crabgrass, shattercane, and woolly cupgrass.

Rooting decreased unequally among species in the same genus. When treated with 324 , 649, and $973 \mathrm{~g}$ PRE CGM $/ \mathrm{m}^{2}$, large crabgrass exhibited $0 \%, 0 \%$, and $45 \%$ root reductions, respectively, and smooth crabgrass had $65 \%$, $95 \%$, and $100 \%$ reductions, respectively. Rooting reductions for yellow foxtail treated with 324,649 , and $973 \mathrm{~g}$ PRE CGM $/ \mathrm{m}^{2}$ were $20 \%$, $20 \%$, and $60 \%$, respectively. At the same levels, reductions were $65 \%, 85 \%$, and $95 \%$, respectively, for giant foxtail and $35 \%, 85 \%$, and $100 \%$, respectively, for green foxtail.

\section{Discussion}

The results of these greenhouse screenings substantiate that the efficacy of CGM as a herbicide may extend to a broad spectrum of monocotyledonous and dicotyledonous plant species (Christians, 1993). All broadleaf and grass species evaluated exhibited some degree of susceptibility to the herbicidal properties of CGM. Plant responses, however, were variable among treatment levels and species. Application method also affected the reductions in shoot length and root development.

The PPI treatments generally were more effective than PRE applications in reducing shoot length and root development in all species, probably due to increased contact between the CGM and the germinating seedlings with the PPI treatment. The roots and shoots of rapidly germinating species may be developed too fully before the PRE treatments become effective.

The efficacy of CGM for control of a particular weed species in a management system depends on the amount of CGM applied. Broadleaf species were generally more susceptible to CGM than grasses, and reductions in shoot length and root development were larger at the lower CGM levels. Black nightshade, common lambsquarters, creeping bentgrass, curly dock, purslane, and redroot pigweed were the most susceptible species and exhibited $\geq 75 \%$ reductions in survival and rooting and $>50 \%$ reductions in shoot length with PRE and PPI at $324 \mathrm{~g} \mathrm{CGM} / \mathrm{m}^{2}$.

Table 4. Reductions in shoot lengths, relative to the control, of weeds treated with three quantities of soilsurface-applied (PRE) and preplant-incorporated (PPI) corn gluten meal (CGM). ${ }^{\mathrm{z}}$

\begin{tabular}{|c|c|c|c|c|c|c|}
\hline \multirow{4}{*}{$\begin{array}{l}\text { Weed } \\
\text { species }\end{array}$} & \multicolumn{6}{|c|}{$\%$ Reduction $^{y}$} \\
\hline & \multicolumn{6}{|c|}{ Quantity of CGM } \\
\hline & \multicolumn{2}{|c|}{$324 \mathrm{~g} \cdot \mathrm{m}^{-2}$} & \multicolumn{2}{|c|}{$649 \mathrm{~g} \cdot \mathrm{m}^{-2}$} & \multicolumn{2}{|c|}{$973 \mathrm{~g} \cdot \mathrm{m}^{-2}$} \\
\hline & PRE & PPI & PRE & PPI & PRE & PPI \\
\hline Annual bluegrass & 27 & 39 & 41 & 29 & 49 & 51 \\
\hline Barnyardgrass & 0 & 12 & 0 & 30 & 0 & 55 \\
\hline Black medic & 51 & 59 & 73 & 75 & 92 & 87 \\
\hline Black nightshade & 66 & 85 & 100 & 100 & 100 & 100 \\
\hline Buckhorn plantain & 22 & 67 & 81 & 89 & 90 & 89 \\
\hline Catchweed bedstraw & 11 & 70 & 46 & 100 & 81 & 100 \\
\hline Common lambsquarters & 70 & 74 & 74 & 95 & 100 & 100 \\
\hline Creeping bentgrass & 47 & 58 & 70 & 70 & 95 & 75 \\
\hline Curly dock & 55 & 75 & 84 & 89 & 90 & 94 \\
\hline Dandelion & 54 & 81 & 83 & 90 & 100 & 100 \\
\hline Giant foxtail & 21 & 56 & 51 & 72 & 64 & 93 \\
\hline Green foxtail & 0 & 62 & 10 & 94 & 100 & 100 \\
\hline Large crabgrass & 0 & 4 & 6 & 49 & 0 & 87 \\
\hline Orchardgrass & 34 & 34 & 45 & 44 & 70 & 88 \\
\hline Purslane & 65 & 100 & 66 & 95 & 83 & 100 \\
\hline Quackgrass & 7 & 50 & 27 & 72 & 22 & 94 \\
\hline Redroot pigweed & 74 & 81 & 81 & 94 & 95 & 100 \\
\hline Shattercane & 45 & 41 & 19 & 64 & 10 & 84 \\
\hline Smooth crabgrass & 44 & 53 & 70 & 71 & 86 & 89 \\
\hline Velvetleaf & 20 & 0 & 42 & 0 & 58 & 79 \\
\hline Woolly cupgrass & 11 & 12 & 18 & 50 & 31 & 81 \\
\hline Yellow foxtail & 0 & 28 & 0 & 87 & 32 & 84 \\
\hline
\end{tabular}

${ }^{2}$ Least significant difference $\left(\mathrm{LSD}_{0.05}\right)=21$ for mean comparisons between PRE and PPI application methods for each species, and $\mathrm{LSD}_{0.05}=30$ for mean comparisons among CGM quantities for each species.

yThese data include results of two studies and are the mean percentages of the shoot length reductions relative to the shoot lengths of the control plants $(n=6)$.

Table 5. Reductions in root development, relative to the control, of weeds treated with three quantities of soilsurface-applied (PRE) and preplant-incorporated (PPI) corn gluten meal (CGM). ${ }^{\mathrm{z}}$

\begin{tabular}{|c|c|c|c|c|c|c|}
\hline \multirow{4}{*}{$\begin{array}{l}\text { Weed } \\
\text { species }\end{array}$} & \multicolumn{6}{|c|}{$\%$ Reduction $^{y}$} \\
\hline & \multicolumn{6}{|c|}{ Quantity of CGM } \\
\hline & \multicolumn{2}{|c|}{$324 \mathrm{~g} \cdot \mathrm{m}^{-2}$} & \multicolumn{2}{|c|}{$649 \mathrm{~g} \cdot \mathrm{m}^{-2}$} & \multicolumn{2}{|c|}{$973 \mathrm{~g} \cdot \mathrm{m}^{-2}$} \\
\hline & PRE & PPI & PRE & PPI & PRE & PPI \\
\hline Annual bluegrass & 50 & 70 & 55 & 90 & 95 & 95 \\
\hline Barnyardgrass & 0 & 35 & 10 & 50 & 30 & 75 \\
\hline Black medic & 80 & 95 & 80 & 95 & 100 & 100 \\
\hline Black nightshade & 85 & 100 & 100 & 100 & 100 & 100 \\
\hline Buckhorn plantain & 70 & 80 & 95 & 100 & 100 & 100 \\
\hline Catchweed bedstraw & 45 & 80 & 55 & 100 & 100 & 100 \\
\hline Common lambsquarters & 75 & 100 & 90 & 100 & 100 & 100 \\
\hline Creeping bentgrass & 95 & 90 & 100 & 100 & 100 & 100 \\
\hline Curly dock & 90 & 90 & 100 & 100 & 100 & 100 \\
\hline Dandelion & 30 & 90 & 95 & 100 & 100 & 100 \\
\hline Giant foxtail & 65 & 85 & 85 & 85 & 95 & 95 \\
\hline Green foxtail & 35 & 95 & 85 & 100 & 100 & 100 \\
\hline Large crabgrass & 0 & 80 & 0 & 90 & 45 & 100 \\
\hline Orchardgrass & 50 & 80 & 85 & 95 & 95 & 100 \\
\hline Purslane & 80 & 100 & 80 & 100 & 85 & 100 \\
\hline Quackgrass & 25 & 75 & 60 & 95 & 75 & 100 \\
\hline Redroot pigweed & 95 & 100 & 100 & 100 & 100 & 100 \\
\hline Shattercane & 5 & 45 & 30 & 75 & 25 & 95 \\
\hline Smooth crabgrass & 65 & 90 & 95 & 100 & 100 & 100 \\
\hline Velvetleaf & 40 & 60 & 70 & 75 & 70 & 90 \\
\hline Woolly cupgrass & 15 & 60 & 20 & 90 & 35 & 100 \\
\hline Yellow foxtail & 20 & 90 & 20 & 100 & 60 & 100 \\
\hline
\end{tabular}

${ }^{\mathrm{z}}$ Least significant difference $\left(\mathrm{LSD}_{0.05}=12\right)$ for mean comparisons between PRE and PPI application methods for each species, and $\mathrm{LSD}_{0.05}=17$ for mean comparisons among the CGM quantities for each species. y These data include results from two studies and are the mean percentages of the root development reductions relative to the root development of the control plants $(n=6)$. 
Turfgrass management systems are restricted to PRE applications of CGM. According to survival, shoot length, and rooting reductions, PRE applications of CGM may provide acceptable control of annual bluegrass, black nightshade, buckhorn plantain, catchweed bedstraw, common lambsquarters, curly dock, dandelion, giant foxtail, orchardgrass, purslane, redroot pigweed, and smooth crabgrass. In addition, competition from the mature grasses in turfgrass areas may increase the degree of weed control.

Corn gluten meal has the potential to be used as a natural herbicide for the control of many broadleaf and grass weed species. More field trials than those of Christians (1993), however, are necessary to confirm the efficacy of CGM for specific weed species in competitive turfgrass and strawberry production systems.

\section{Literature Cited}

Bonner, J. 1950. The role of toxic substances in the interactions of higher plants. Bot. Rev. 16:5165.

Chou, C. and Z.A. Patrick. 1976. Identification and phytotoxic activity of compounds produced during decomposition of corn and rye residues in soil. J. Chem. Ecol. 2:369-387.

Christians, N.E. 1991. Preemergence weed control using corn gluten meal. U.S. Patent 5,030,268.

Christians, N.E. 1993. The use of corn gluten meal as a natural preemergence weed control in turf. Intl. Turfgrass Soc. Res. J. 7:284-290.

Cochran, W.G. and G.M. Cox. 1957. Experimental designs. 2nd ed. Wiley, New York.

Guenzi, W.D. and T.M. McCalla. 1962. Inhibition of germination and seedling development by crop residues. Proc. Soil Sci. Soc. Amer. 26:456458.

Nielsen, K.F., T.F. Cuddy, and W.B. Woods. 1960 The influence of the extract of some crops and soil residues on germination and growth. Can. J. Plant Sci. 40:188-197.

Nonnecke, G.R. and N.E. Christians. 1993. Evaluation of corn gluten meal as a natural, weed control product in strawberry. Acta Hort. 348:315-320.

SAS Institute. 1990. SAS/STAT user's guide. vol. 1 Anova-Freq. 4th ed. SAS Institute, Cary, N.C. 